Literature Reviews

\title{
Modification of Accusation in the Court of First Instance, Comparative Aspects - A Legal Instrument Accessible to the Specialists in Criminal Matters
}

\author{
Delia Magherescu \\ Gorj Bar Association, Tg-Jiu, Romania
}

\author{
Article history \\ Received: 19-12-2018 \\ Revised: 18-01-2019 \\ Accepted: 30-04-2019 \\ Email: delia_magherescu@yahoo.com
}

\begin{abstract}
The specialists in the area of law, in particular in criminal matters, are often faced with serious challenges of complying with the legislation into force, in the criminal causes they are invested with, either as investigators or as judges or even simply as participants, others than judicial bodies. It is about the experts, lawyers, a.s.o.
\end{abstract}

Keywords: Modification of Accusation, Judicial Function, Defendant's Rights, Right of Defense

\section{Introduction}

The participants in criminal proceedings, either as judicial bodies or lawyers or experts, are often faced with serious challenges of complying with the legislation into force in the criminal causes they are involved in, on the one hand.

They must be inured with the jurisprudence aspects in the matter as well as with the doctrine, on the other hand.

From this point of view, a paper which comprises together both the doctrinaire issues and legislation as well as the jurisprudence references, is certainty a complex research study.

The book having the topic on the modification of accusation in the court of first instance, comparative aspects is an effort in this matter, one which the author tries to relate in detail, through the subject approached and the manner of the legal institutions presented.

Published with the Wolters Kluwer Publishing House in Bucharest, the second edition of the work is devoted to the legal institution of Criminal procedure law - the modification of accusation in the court of first instance. It was elaborated based on the last legislative modifications in criminal matters, more specifically after the Romanian Code of penal procedure entrance into force on the 1st of February 2014. Moreover, the paper approaches the issue of the modification of accusation from the point of view of the several decisions pronounced by the Constitutional Court of Romania regarding the exceptions of unconstitutionality of some provisions of the Code of penal procedure (Magherescu, 2016).
The book is structured in three titles, each of them being organized in chapters and sections.

Title I, having as topic on the general considerations regarding the accusation, introduces the reader in the core of the accusation legal features, exercising the penal action, the communication of accusation, the factors which establish the accusation as well as the legal consequences they produce in practice.

The principle of exercising the judgment function within the formulated accusation limits is analyzed within the second Chapter from the point of view of the role the "equality of arms" has during the penal trial in Romania, as well as the way in which it determines the factors which generate the modification of accusation in the court of first instance (Magherescu, 2004a). In this procedural context, a precise making evidence of the judicial functions separation of accusation and judgment during the penal trial is emphasized. At the same time, the entire parties' procedural guarantees, in particular the defendant's ones are respected in the penal trial. (Magherescu, 2006).

The author also points out the concise definition of the modification of accusation and the classification criteria of such a legal institution of penal procedure law. Basically, it is appreciated that "most of the accusations modified are part of the penal cases in which the initial accusation is incomplete and incorrect formulated. "In order for the judicial bodies to rectify such gaps, they must proceed to excluding the parts of accusations for which there are no conclusive, pertinent and reasonable evidence, or in accordance with the article 386 Code of penal procedure, they use changing the offence legal integration through "exchanging some articles or penal provisions with other ones". 
Moreover, the author emphasized the prosecutor's role and procedural position during the penal trial. Within the research, both the affirmative and negative theories on the prosecutor's legal position in the penal trial are pointed out, relating in detail in favor of both thesis and against them as well.

The Title II focuses on the legal modalities of achieving the modification of accusation in the first instance court. Each of these modalities is researched from the point of view of the differences among them, taking into account their different legal feature, particular content and, last but not least, legal consequences they produce. These modalities involve several types of modification. However, the legal institution of the modification of accusation by nonaggravating the defendant's legal situation is relevant for the entire study. It is defined as being "the typical modality of achieving the modification of accusation", instead of the other ones which are considered atypical modalities of modification of accusation, knowing the fact that, at the moment, the last ones are not regulated in the Code of penal procedure into force any more.

The study of the jurisprudence in criminal matters highlighted the fact that discussing about the modification of accusation in the court of first instance on non-aggravating the defendant's legal situation, two specific modalities are distinguished. The first one is connected to "the accusation content,, while the second modality refers to the "offence legal integration or qualification" (Magherescu, 2004b). Moreover, it is distinguished between the modification of accusation in the substantial meaning and the modification of accusation in the juridical meaning.

Analyzing the jurisprudence in criminal matters on disposing the modification of accusation by the court of law, a particular situation has been highlighted regarding the set of attenuated circumstances and the second offence. Nevertheless, the doctrine has been reticent on the right of reducing the penalty under special minimum regulated by the penal law, in criminal cases in which there is a set of attenuated circumstances and the second offence, in accordance with the previous Code of penal procedure.

It is also pointed out that indifferent of the way of achieving changing the offence legal integration supposes two obligations that must be carried out by the court of first instance (Magherescu, 2005a). The first one consists in providing the parties with the new offence legal integration, while the second obligation refers to informing the defendant on his right of postponing cause in order to prepare the defense in conformity with the new accusation the court of law decided on. This procedure is regulated by the article 386 of the Romanian Code of penal procedure.

One of the most important issues stated by doctrine which have arisen a real controversy among specialists in criminal matter refers to the penal sanctions which intervene in cases in which the court of law does not inform the defendant on changing the offence legal integration. Regarding the parties' rights, the sanction in such cases is the relative nullity, if the court of law comes out that the parties' procedural damages cannot be redressed.

The Title III is devoted to the correlations between the modification of accusation in the court of first instance and the other penal procedure institutions. It has been identified, in this matter, the legal procedure of restoring the penal case to prosecutor and the legal institution of nullity sanction which derives from the non-observance of the legal provisions of the modification of accusation.

Regarding the sanction of nullity, it was differently analyzed depending on the kind of nullity, such as the sanction of nullity resulted from the non-observance of the legal provisions regarding the guarantee of the defendant's right of defense and the sanction of nullity resulted from the non-observance of the legal provisions regarding the notification of the court of law.

The right of defense is stated from the point of view of the international convention and treaties Romania is a part of. They are applied during the penal trial of Romania, as a consequence they have priority in the home legislation, once they have been ratified by the Romanian Parliament. The right of defense offers real procedural guarantees for defendant during the entire penal trial. Linked to this concept, it is emphasized the right of defense is not limited to the legal assistance provided by the lawyer - defender - but it is only a part of such right.

Regarding the legal institution of the modification of accusation, it is also pointed out the fact that these legal guarantees they have been enunciated above "are substantially increased and actuated at the time of occurring the modalities of achieving the modification of accusation in the court of first instance" (Magherescu, 2016).

The research is supplemented by the jurisprudence aspects. Relevant decisions pronounced by the national law courts on the modification of accusation in the first instance. Moreover, the jurisprudence elements of the other jurisdictions, such as France, Germany and Italy are stated.

The research paper is also drawn up by using the comparative law which offers it an added scientific value. The most significant aspects related to the modification of accusation in other penal procedure legislations have been succinctly pointed out. Although there are significant differences among the judicial systems, certain similarities on the offence legal qualification and its modification in the court of law have been identified (Magherescu, 2005b). The idea of the Romanian Code of penal procedure being of both French and Italian inspiration has been taken into consideration.

Moreover, the author emphasizes the importance of the principles of penal procedure law applied during the 
penal proceedings, including the principles of common law judicial system both from the United States of America (Bohm et al., 1999) and from the British penal system (Elliot and Quinn, 2000).

At the same time, the most relevant aspects related to the accusation in the Italian penal justice are discussed in a comparative manner. Moreover, the author highlights its particular feature from the point of view of the opportunity of formulating accusation in accordance with the offence committed (Cordero, 2000) as well as from the point of view of the consequences produced (Ubertis, 2001).

Doctrine of French penal procedural law also offers a general framework for the judicial institutions of solving penal cases in the court of first instance. Certain prestigious authors' opinions in this matter, such as Jean Pradel (2000; Franchimont et al., 1989) and Soyer (2003) are emphasized in this book.

The paper is based on the varied document references both at the national and international levels. (Code of Penal Procedure of Romania, 2010; European Convention of Human Rights, 1950; International Covenant on the Civil and Political Rights, 1966).

\section{Conclusion}

The monographic book is based on a research study on the legal institution of the modification of accusation in the court of first instance. It is supplemented with comparative elements from the European states doctrine and jurisprudence as well as from the United States of America.

In carrying out the book, the author has taken into account the legislation in criminal matters intervened after adopting the new Romanian Code of penal procedure entered into force on the $1^{\text {st }}$ of February 2014.

Based on such research activity, specific proposals of de lege ferenda have been provided, proposals which could be taken into consideration by the legislator supposing that the legal framework in penal justice will be improved.

From a theoretical point of view, the author was looking for defining the procedure of modification of accusation as well as for the conditions the accusation must achieve in purpose not to be considered a vitiated one. It has been demonstrated that only by respecting such conditions the accusation will not be susceptible of modification from subjective motives. Otherwise, those accusations based on the objective conditions must be modified by the judicial bodies.

From the jurisprudence point of view, the contribution to perfection of mechanisms of solving penal cases in accordance with the observance of the parts' procedural rights during the penal proceedings has been pointed out in this book.

Taking into account all these aspects stated in the current literature review, it is obvious that the book on the modification of accusation in the court of first instance comparative aspects could be considered a referential research work for the lawyers in the area of criminal law and, for this reason, it can be recommended for lecture.

\section{Acknowledgement}

I would like to express my gratitude to the JSS Editorial Board members who invited me and supported me to publish my research contributions with the Journal of Social Sciences as being the largest international journal in the field of social sciences. Subsequently, I also would like to thank to the anonymous reviewers who appreciated my work and approved it in order to be published in this journal.

\section{Ethics}

There is no ethical issue and conflict of interest related to the paper published.

\section{References}

Bohm, R. M. and Haley, K. N. 1999. Introduction to Criminal Justice. 2nd Edn., McGraw-Hill Companies, New York, ISBN-13: 9780028028248 , pp: 517.

Code of Penal Procedure of Romania, 2010. Adopted by Law no. 135/2010, published into Romanian Official Journal no. 486 of 15 July 2010. Entered into force in 2014. In vol. Noul Cod pena. Noul Cod de procedura penala, C.H.Beck Publishing House, Bucharest. ISBN-13: 9786061802456, pp: 743.

Cordero, F. 2000. Procedura penale. vol. VI. 5th Edn., Giuffre. Milano. ISBN-10: 8814081786, pp: 1260.

Elliot, C. and F. Quinn, 2000. Criminal Law. 3rd Edn., Harlow Longman. ISBN-13: 9780582423527, pp: 318.

European Convention of Human Rights, 1950. Entered into force in 1953. Council of Europe, Cedex, Strasbourg.

Franchimont, M., Jacobs, A., Masset, A. 1989. Manuel de procédure pénale in vol. Collection scientifique de la Faculté de droit de l'Université de Liège. Jeune Barreau. Liège. ISSN: 1784276X, pp: 1157.

International Covenant on the Civil and Political Rights, 1966. Entered into force in 1976. https://www.ohchr.org/en/professionalinterest/pages /ccpr.aspx

Magherescu, D., 2004a. Unele aspecte privind cauzele care genereaza modificari ale invinuirii in prima instanta (Certain aspects regarding the causes which generate the modification of accusation in the first instance). Scientific Annals USM, 1: 9975-70-144-2. 
Magherescu, D., 2004b. Modalitatea juridica a modificarii invinuirii in sens juridic (The legal modality of modification of accusation in juridical matter). Scientific Annals of the USM, 1: 9975-70-144-2.

Magherescu, D., 2005a. Discutii in legatura cu modificarea invinuirii in sensul neagravarii situatiei inculpatului in dreptul francez. National Review of Law, 3: 811-0770.

Magherescu, D., 2005b. Schimbarea incadrarii juridice a faptei-Consecintele nepunerii in discutia partilor. Proceedings of the 2nd International Scientific Conference "Economy and Globalisation". Jun. 3-4, Tg-Jiu, Romania, Universitaria Craiova Publishing House, pp: 515-517.
Magherescu, D., 2006. Aspecte privind functia de invinuire si functia de judecata. National Review of Law, 1: 1811-0770.

Magherescu, D., 2016. Modificarea Invinuirii în Prima Instanță. Aspecte Comparative. 2nd Edn., Wolters Kluwer Publishing House, Bucharest. ISBN-13: 978-606-677-017-0, pp: 223.

Pradel, J., 2000. Manuel de procédure pénale, Cujas, Paris. ISBN-10: 2254004107, pp: 862.

Soyer, J.C., 2003. Droit pénal et procédure pénale. 17th Edn., LGDJ Paris. ISBN-10: 2275019480, pp. 443.

Ubertis, G., 2001. Codice di Procedura Penale e normativa Complementare. 9th Edn., Cortina Raffaello, Milano. ISBN-10: 8870787230, pp: 1038. 